\title{
양허성 원조차관(Aid Loans) 제공의 실질비용과 제약요인
}

정 우 용 / KOICA 이집트 사무소장

\section{I . 머리말}

적어도 1996 년의 $\mathrm{OECD}$ 개발원조위원회(DAC) 가 채택한 " 21 세기의 구상: 개발협력의 공헌”과 2000년 유엔의 “천년개발목표(MDGs)" 설정 이후 개발협력의 이념은 변하고 있다. DAC와 유엔의 이같은 새로운 원조패러다임 설정은 더 이상 원조 공여국들이 자국의 경제 - 정치적 이익실현을 위한 도구로서 원조를 적극 활용하는 시대로부터 이제 는 개도국의 개발 지원이라는 원조 본래의 목적에 보다 충실한 개발협력파트너로서의 원조를 수행토 록 권고하고 있다. 이제 원조공여국들은 자의든 타 의든 자국의 원조정책과 방향을 대세적 흐름에 부 합되게 수정하지 않을 수 없게 되었다. 이제 제법 원조규모가 커지게 된 우리나라로서도 $\mathrm{DAC}$ 에 가 입을 하지 않았다는 이유로 이러한 시대적 흐름을 무시할 수가 없고 또 2009년까지 중기원조확대 계 획을 수립해 놓고 있는 상황 하에서 원조의 효율적 인 사용과 원조를 통한 국익증대를 위해서도 국제
사회의 대외원조 논의과정을 주의 깊게 살펴보고 향후 원조수행에 적극 대처해야 할 필요가 있다. 워낙 원조자체의 이념이 크게 변하고 있고 대외원 조에 관한 국제적 연대가 과거보다 더 공고히 이루 어지고 있기 때문에 우리가 그동안 해오던 우리식 의 원조방법과 규범을 유지하기가 무척 어려워질 것으로 예상되기 때문이다.

특히 산업인프라 구축 등에 필요한 양허성 자금 을 지원하여 개도국의 빈곤 완화에 도움을 주는 동 시에 우리기업과 물품의 해외진출이라는 목적으로 도 긴요하게 활용되어 온 원조형태의 하나인 타이 드 론 (Tied loans)의 향후 위상이 더욱 위축될 것 으로 예상된다. 수원국의 입장에서는 무상보다는 큰 자금 규모의 유상의 형태로 원조를 받을수록 부 족한 자금수요에 효과적으로 대처할 수 있으나 국 제수지상 상환부담은 커질 수 있고, 공여국의 입장 에서는 차관을 상환 받을 수 있다는 점에서 재정부 담을 감소시킬 수 있으나 차관의 실질비용'을 재산

1) 타이드원조 공여로 인한 직 - 간접적인 수출효과는 유 - 무상 모두 비슷 하다고 가정하여 본고에서는 이를 다루지 않기로 한다. 
정해 보면 당초 기대했던 명목비용보다 재정부담 이 크게 증대될 수 있다. 그러나 양측의 이해를 떠 나서 $\mathrm{OECD}$ 타이드 원조규제에 따라 실질적으로 타이드 론 활용이 크게 제약을 받을 전망이다. 이 하에서는 공여국의 관점에서 본 타이드 원조차관 의 장단점 등에 대한 논점을 점검해보고 그와 관련 된 정책적 시사점을 살펴보고자 한다.

\section{II. 원조로서의 양허성 차관제공의 타당성}

차관(Loans)과 증여(Grants)의 차이는 차입금 의 상환의무 발생여부이다. 원조(aid)란 무상의 형 태만이 아니다. $\mathrm{DAC}$ 정의에서 보듯 일정한 양허 성 (Concessionality)을 가진 차관도 원조의 범주 에 속한다. 개발원조의 한축으로서의 양허성 차관 은 그간 재원이 부족한 개도국에 경제 - 사회발전 에 필요한 장기저리의 개발자금을 공급하는 역할 을 해왔다. 증여보다 차관의 사용을 선호하는 주요 이유를 공여국의 관점에서 보면 원리금을 상환 받 음으로써 자금 부담이 명백히 감소된다는 것과, 수 원국의 입장에서는 상환할 필요가 없는 증여보다 차관으로 차입한 자금을 보다 주의깊게 사용할 것 이란 믿음 때문이다. 반면 원조로서의 양허성 차관 의 사용을 회피하는 주장은 우선 개도국의 부채가 이미 과도한 수준이고 채무이행을 관리할 개도국 의 제한된 제도적 역량을 들고 있다. 또한 양허성
차관이 민간자본의 역할을 저해하고 경쟁적 위치 를 왜곡시키고 희소자원을 배분하는데 있어 이자 율의 기능을 약화시킨다는 것이다. 따라서 양허성 을 가진 차관 공여가 수원국의 입장에서 재정통화 적 시스템을 대체하지 않도록 하는 주의가 필요하 다는 것이다. 이하에서는 양허성 차관 제공의 타당 성 근거에 대해 우선 살펴보기로 한다.

\section{1. 자본의 부족}

대부분의 개도국의 경우 경제성장에 필수적인 생산요소인 자본이 부족하기 때문에 외국자본을 수입하여 국내 투자수요를 보충한다. 투갭(Two $\mathrm{Gap}$ ) 모델이 설명하듯이 개도국의 경제성장을 위 해서는 충분한 자금의 흐름이 저축과 외환 부족분 을 충당해줘야 하며 따라서 외국원조의 역할은 저 축과 투자, 그리고 수입과 수출의 두개의 갭을 채 워줘야 한다는 것이다. 경제발전에 필요한 투자자 금은 어느 정도 상업차관을 통해 조달할 수 있으 나 민간자금시장은 국제 자본 시장의 불완전성 때 문에 원조자금 공급이라는 대체기능을 원활히 할 수 없다. 예컨대 설사 민간자본시장이 중고소득 개도국에 신용자금을 공급할 수 있더라도 대부분 의 개도국은 그 특수한 경제적 조건 및 위치 때문 에 ${ }^{2)}$ 그 시장에의 접근에 제약이 많다. 개도국으로 서는 높은 투자수익율을 가져다주는 경제·사회 인프라 프로젝트에 많은 투자자본이 필요하나 최 종 산출물은 대개 초기에는 수익을 창출하지 못하 고 보통 장기간(예: 30-40년)이 지나서 실현된다.

2) 예를 들면 개도국은 국가위험도(Risk)를 가지고 있거나 자금을 지원받는 프로젝트가 수익성이 부족할 때가 많다. 
따라서 민간자본시장에서는 이러한 장기투자에 필요한 재원의 조달이 쉽지 않게 된다. 그러므로 양허성 조건의 장기차관이 최소한 개발초기 동안 에는 민간자본시장에서의 자본흐름에 보충하여 필요하게 된다.

\section{2. 채무완화}

개도국의 과도한 채무 때문에 개발원조는 더욱 양허적이어야 한다는 주장이다. 실제로 많은 원조 기관들은 개도국의 채무증가에 우려를 나타내고 양허적인 조건의 원조를 제공하고 있다. 수출을 통 해 획득하는 외환고를 넘어서는 채무증가가 차관 의 거치기간을 연장한다든지 또는 이자율을 낮춘 다든지 하는 연성화(Softening)의 중요 논거이지 만 사실 개도국의 부채 문제는 연성의 원조차관의 공여 때문이기 보다는 기본적으로 상업적 조건의 차관의 과다 차입 때문이다. ${ }^{3}$ 개도국이 외채를 상 환하기 위해서는 국내자본을 증대하여 외환을 확 보하여야 하지만 인프라 투자에 많은 재정적 소요 가 필요한 개도국으로서는 수출을 급격히 증대시 킬 수 있는 능력을 제한하는 제도적 제약이 존재한 다. 마이크셀(Mikesell, 1968)이 주장하듯이 양허 성 차관은 지속적인 개발과정에 필요한 조건들을 얻지 못하는 국가들에게 구조적 변화를 유인하고 촉진하는데 필수적이라 한다. 따라서 양허성 자금 은 시장조건의 자금보다는 상대적으로 과도한 외 채 상환과 외환부담을 발생시키지 않으면서 개도 국들이 필요한 투자를 위해 차입할 수 있는 기회를
증가시키게 된다.

\section{3. 자원의 합리적 사용}

차관 사용의 또 하나의 타당성은 차관이 무상보 다 더 효율적으로 사용될 수 있다는 주장이다. 왜 냐하면 차관은 상환의무가 있기 때문에 수원국은 지출에 있어 보다 신중해지고 검약하게 사용할 수 밖에 없으며 따라서 자금의 보다 합리적인 사용을 가져오게 한다는 것이다. 이러한 주장은 수원국의 자조노력(Self-help efforts)을 강조하는 일본의 엔차관 제공의 철학적 기반을 제공해 주고 있다고 볼 수 있다. 이런 점에서 스타인버그(Steinberg, 1985)는 한국은 원조 효과성 측면에서 1960년대와 1970년대에 모델 수원국이었다고 지적한 바 있다. 원조 효과성을 자금의 지출과 관련지어 볼 때 한국 은 일반적으로 자금의 사용에 있어서 신중하였다 는 것이다. 더구나 투자수익율이 일반적으로 개도 국에서 높기 때문에 양허성 원조는 자원사용에 있 어 수원국뿐만 아니라 세계 전체에 높은 수익율을 달성할 수 있는 효율성을 가져다 준다. 이것은 자 본의 상이한 수익율 때문에 개도국과 선진국간의 할인율(Discount rate)에 차이가 발생하는 것과 관련이 있다. 이 할인율은 보통 자본의 기회비용을 나타내는데 차관제공의 타당성의 근거 중의 하나 는 개도국의 투자자본의 기회비용이 선진국의 그 것보다 높다는 가정에 근거하고 있다. 따라서 차관 이 무상보다 더 효과적으로 사용되려면 자금 공여 국의 할인율이 차입국보다 낮아야 한다는 것이다. 
즉 그러한 자금의 이전으로 수원국도 이익을 얻을 수 있을 뿐만 아니라 사회전 체로서도 자본을 더 높은 수익율을 발생시킬 수 있는 활동에 투입함으 로써 사회 전체로서도 이익을 보게 된다.

\section{III. 원조로서의 차관 제공의 한계}

위에서 살펴본 바와 같이 차관이 개도국의 경 제· 사회개발에 일정부분 기여할 수 있다는 여러 논거들에 불구하고 차관 제공의 단점으로 지적되 고 있는 것은 수원국의 경제사회발전에 필요한 투 자에 대한 차관의 효과성의 위축, 차관의 실질비용 을 감안할 때 무상원조 못지 않는 재정부담의 증가 의 예상, 그리고 $\mathrm{OECD}$ 의 타이드 원조 규제에 따른 실질적인 차관운용에의 제약 등을 들 수 있다.

\section{1. 경제 · 사회적 효과성의 위축}

원조로서의 차관의 단점으로 우선적으로 거론 되는 것은 기본적으로 차관이 중장기적으로 수원 국이 상환하여야 하는 자금이기 때문에 원조의 효 과성을 위축시킨다는 점이다 (Martens, 2001). 설 령 이자율과 상환조건이 시장조건보다 더 유리하 다고 할지라도 이러한 자금은 단지 일시적인 원조 일수밖에 없을 뿐만 아니라 공여국이 당초 원조에 의해 지불했던 것보다 종국에는 더 많은 자금이 공 여국으로 돌아오게 된다. 따라서 차관을 많이 공여 받을수록 수원국의 외채는 더욱 증가하게 된다. $\mathrm{DAC}$ 회원국중 최대의 $\mathrm{ODA}$ 차관 공여국인 일본에
대해서는 2002년말 기준 개도국은 970억불(최빈 국의 80억불 포함)의 부채를 지고 있고 이는 두번 째로 큰 차관 공여국인 독일(220억불)의 4배가 넘 는 규모이다. 공여국의 차관제공에 따른 수원국의 외채증가에 따라 선진국들은 부채감면 내지 탕감 이라는 문제에 불가불 직면하게 된다. 보통 최빈국 에게는 $\mathrm{ODA}$ 부채 부담이 더욱 경감되어지는데 1978년 UNCTAD에서 결의한 “소급조건조정” (Retroactive Terms Adjustment)에 따라서 DAC 회원국들은 과거 기 제공 $\mathrm{ODA}$ 차관의 조건을 재 조정하여 $\mathrm{ODA}$ 의 재무적 조건을 개선시켰다. 이 조정으로 약 60 억불의 자금이 최빈국을 포함한 45 개국 이상의 개도국에 혜택을 가져다 주었고 외채 의 30억불 이상이 소멸된 바 있다 $(\mathrm{OECD}, 1985$ :70). 1996년에는 세계은행과 국제통화기금(IMF) 주도로 고채무빈곤국(HIPC) 이니셔티브를 창설하 여 아프리카와 중남미등의 빈곤국에 부채를 탕감 하기위한 프로그램을 진행 중에 있다. 보다 최근 2005년 7월에 개최된 스코틀랜드 G8정상회의에 서는 외채가 많은 18 개국에 대해서 세계은행과 $\mathrm{IMF}$ 에 지고 있는 400 억불의 빚을 탕감키로 결의 하였다. 그러나 그것도 세계은행 등 국제기구에 진 빚만 탕감되는 것이고 민간 부채는 제외되지는 않 는다.

그렇다고 차관이 항상 긍정적이지 않은 효과만 을 가져오는 것은 아니다. '차관' 이 경제적으로만 투자된다면 부채는 크게 문제되지 않을 수 있으며 일정한 제한적 조건하에서는 효과를 볼 수 있다. 이미 언급하였듯이 개도국이 차입된 자금을 상환 
하려면 그것이 생산적으로 투자되어져야 한다. 그 럴 경우 개도국의 저축과 투자의 갭을 보충함은 물 론 성장률을 증대시킬 수 있고 따라서 앞으로 차관 을 상환하는데도 도움이 될 것이다. 그러나 문제는 차관이 생산적으로 투자되지 않거나 투자보다는 소비증대를 위해 사용될 때가 있다는 것이다. 따라 서 수원국은 소비나 비생산재 구입을 위한 차관의 사용을 억제하고 수익이 부채상환을 감당할 수 있 는 고수익투자에 사용되어져야 한다.

둘째, 차관이 수출증대를 위해 사용될 때이다. 즉 수원국은 채무를 외환으로 상환하여야 하기 때 문에 당해 프로젝트가 추가적인 수출 소득으로 직 간접적으로 필요한 외환을 획득할 수 있어야 한다.

셋째, 개발차관이 투자의 회임기간 (gestation) 이 비교적 길고 낮은 수익율을 산출하는 프로젝트 에 투자되는 경향이 있기 때문에 상환기간 중 원리 금의 상환액이 상승하게 되면 차관이 리스크에 노 출될 수 있다. 특히 부채가 외채일 때 상환은 외환 으로 이루어지기 때문에 수입보다는 수출을 더 증 대시켜 국제수지 $(\mathrm{BOP})$ 를 흑자로 전환시켜야 한 다. 다시 말하면 수원국은 국민경제 전체 차원에서 프로젝트가 수원국의 국제수지를 충분히 개선시켜 서 차관의 이자 지불 뿐만 아니라 원금도 상환할 수 있어야 한다. 여기서 국제수지에 영향을 미치는 투자의 2 차적인 효과(예: 원자재, 1 차 산품, 부품등 의 수입증가)도 고려하여 국내생산기반을 지속적 으로 구축해서 그러한 2 차 수입을 상쇄시킬 수 있 어야 한다. 그러나 이러한 기준들은 개발에 있어서 의 차관과의 양립성 판단에 필요할지는 모르나 충
분한 조건은 아니다. 필요한 외환을 획득할 수 있 는 고수익 투자라도 향후 발생할 수 있는 부정적인 사회적 또는 환경적 영향 때문에 국가의 지속가능 개발에 폐해를 초래할 수 있다. 더구나 그 프로젝 트가 타당할지라도 외국차관은 추가로 외환을 획 득할 필요를 증가시켜 국제무역과 국제 자본 시장 에서 장기적 의존을 더하게 된다. 이러한 기준으로 볼 때 충분한 수익율 또는 외환확보를 보장하지 못 하는 개발프로젝트가 결국 문제가 된다. 이것은 기 본적인 사회적 서비스를 위한 차관에 적용될 뿐만 아니라 환경보호, 역량구축(Capacity Building), 수출 지향적이지 않는 농업생산 지원을 위한 차관 에도 적용된다. 따라서 상기 논거들은 $\mathrm{ODA}$ 가 무 상의 형태로 제공되어져야 한다는 주장을 뒷받침 하고 있다.

\section{2. 타이드원조 차관의 실질비용의 증가}

원조비용은 수원국의 이익과 공여국의 비용으 로 구분하여 측정해 볼 수 있다. 일반적으로 양허 성이 높을수록 상환액이 감소하게 되어 수원국에 게는 유리하게 되지만 공여국에게는 그만큼 비용 이 더 소요된다. 공여국의 원조비용은 수원국이 관 심을 갖는 부분이 아닌 공여국의 부담을 나타낸다 고 볼 수 있지만 타이드 원조로 인한 양허성 감소 효과는 수원국의 관점에서 본 원조비용 측정이라 고 볼 수 있다. $\mathrm{DAC}$ 의 양허성 산출방법은 그간 여 러 문제점들이 지적되어 왔는데 우선적으로 각국 의 여건을 고려치 않은 일괄적인 고정할인율 $10 \%$ 적용의 문제점과 기타, 차관상환에 실질적으로 영 
향을 미치는 물가상승이나 환율변동을 감안하고 있지 않는 점이다. 차관의 경우 일반적으로 $10 \%$ 기준보다 높은 할인율이 적용되면 양허성이 증가 하게 되어 공여국의 비용이 증가된다. 특히, 우리 나라의 타이드 론인 대외경제협력기금 (EDCF 차 관)의 경우는 원화를 대출하여 수원국으로부터 원 화로 상환받게 될 때 그 가치가 국내 물가 상승이 나 원화의 평가절하 같은 환율 변동이 발생할 경우 공여국의 입장에서는 원화의 가치하락으로 인해 수원국이 부담 하여야 할 양허성은 증가하는 효과 를 가져 온다. $10 \%$ 의 고정 할인율은 $\mathrm{DAC}$ 가 정한 자의적인 수치이나 이자율과 함께 양허성 산출에 매우 크고 민감한 영향을 미친다. 공여국 각국의 할인율이 사용된다면 보다 정확한 양허성을 산출 해 낼 수 있고 따라서 적용 할인율에 따라 공여국 의 비용이 달리 측정될 수 있으나 적정 할인율 측 정은 명확한 산정기준은 존재하지 않는 주관적 선 택의 어려운 문제이다. 다만, $\mathrm{OECD}$ 는 타이드 원 조 적격심사와 관련하여 증여율과 유사개념인 양 허성 수준(Concessionality Level)을 사용 하는데 보통 상업참고금리(Commercial Interest Reference Rate: CIRR)를 각국의 할인율로 표시 하여 산출하고있다. 우리나라의 $\mathrm{EDCF}$ 차관의 경 우 상환기간별로 차등 적용되는 마진(margin)을 포함하여 2001년까지는 $10 \%$ 이상의 CIRR을 적용 하였으나 2002년부터는 $10 \%$ 이하로 하락되고 있 다. 즉 2001년까지는 CIRR 기준으로 볼때 명목 양허성 및 공여비용이 저평가되어왔다고 볼 수 있 다. 한편, 차입한 자금의 경제적 가치는 시간이 경
과함에 따라 인플레이션으로 실질적으로 감소하게 되는데 이것이 하비(Harvey, 1983)가 일컬은 전 세계적인 인플레이션으로부터 얻어지는 소위 '차 입자의 이익' 이다. 공여국의 입장에서는 양허성 측정시 인플레이션을 고려하지 않으면 대출부담이 실질적으로 감소하기 때문이다. 결과적으로 양허 성이 인플레이션을 무시함으로써 저평가되어온 것 이다. 차관의 상환흐름을 명목기준에서 실질기준 으로 전환하기 위해서는 향후의 인플레이션율을 예측하고 상환액을 인플레이션율로 디플레이트해 야 한다. 또한 차관의 상환은 환율변동, 특히 자국 화폐의 평가절하로 위협받을 수 있다. 그러한 차관 은 장기간 대출되므로 미래의 예측 못할 통화 불안 정에 취약할수 있기 때문이다. 즉, 환율의 변동은 외화 차입자에게 흔히 위험을 초래하기도 하나 공 여국의 입장에서도 자국의 화폐가 지속적으로 평 가절하 된다. 따라서 수원국의 입장에서는 그만큼 상환부담이 감소하게 되며, 공여국으로서는 대출 한 자금의 양허성이 증가하는 효과를 가져온다. 우 리나라의 $\mathrm{EDCF}$ 차관의 경우 수원국은 원화가 평 가절하되면 상환해야 할 외환 (예: 미달러화)으로 표시된 원화상환액이 감소하게 되므로 수원국의 입장에서 유리하게 된다. 따라서 공여국의 입장에 서는 원화가치가 인플레이션이나 평가절하로 인해 차관공여후 동일한 원화라도 그 가치가 하락하므 로 상환액의 가치는 당초 기대보다 하락하게 된다. 미래를 예측하기란 물론 어렵고 설사 예측이 가능 하더라고 먼 미래로 더 나아갈수록 신뢰성은 하락 하게 된다. 자금공여국의 입장에서 보면 지난 수 
년간 경험하였던 비율정도로 인플레이션이 진행될 것으로 조심스럽게 가정해 볼 수 있다. 전 세계적 으로 경제발전이 진전될수록 인프레이션율이 예외 적으로 하락할 때도 있지만 대개는 플러스의 추세 로 가는 것이 보통이다. 환율의 변화도 마찬가지로 지난 수년간의 변동추이를 분석하여 향후의 추세 를 예측하여 가정하여 볼 수가 있다. 우선 $10 \%$ 의 명목 할인율과 인플레이션율을 가지고 양허성의 변화를 예측해보면, 2004년도 $\mathrm{EDCF}$ 명목양허율 은 평균 $70.1 \%$ 로서 지난 15 년간 (1990-2005)의 연평균 물가상승률인 $4.5 \%$ 를 적용하여 재계산하 면 실질 양허율 $(\mathrm{P})$ 이 $82.2 \%$ 로 크게 상승한다(표 참조). 실질 상환분의 현재가치가 감소되었기 때문 이다. ${ }^{4)}$ 또한 마찬가지로 1990-2005년간의 대미 원화환율의 연평균 변동율(-2.3\%)이 차관의 상환 기간중 유지된다고 가정하면 실질 양허율(e)은 인 플레이션 효과에 추가하여 $85.8 \%$ 로 증가하게 된 다. 즉 인플레이션율과 환율변동율을 감안할 때 실 질적으로 증여율이 $15.7 \%$ 상승하게되어 당초 명목 양허성을 기준으로 한 부담보다 더 큰 부담을 국민 경제에 미치게 된다. 대안으로서 양허성 수준(CL) 산출시 적용되는 $\mathrm{CIRR}$ 을 기준으로 실질 양허성을 측정해 볼 수 있다. 2004년도에 적용되는 1.15 의 마진을 포함한 $7.04 \%$ 의 할인율 5 을 적용하면 $10 \%$ 의 명목 할인율 적용시 보다 낮은 수준인 $56.3 \%$ 의 양허성이 산출된다. 마찬가지로 상기의 인플레이 션과 환율변동율을 적용하면 실질증여율은 각각

$75.7 \%, 81.3 \%$ 로 증가한다. 따라서 $10 \%$ 의 증여율 을 기준으로 한 명목 양허성은 CIRR 적용 및 물가 상승율, 그리고 환율변동율을 감안하면 실질 증여 율이 $11.2 \%$ ( $81.3 \%$ - 70.1\%) 상승하게 된다. 만일 매우 큰 폭의 인플레이션율과 환율하락이 발생하 는 상황을 가정해보면 증여율은 $100 \%$ 이상을 초 과하는 극단적인 경우도 발생할 수 있는 바 이때는 유상이 무상보다 오히려 더 큰 부담을 가져다 주는 사례가 된다.

\section{〈EDCF차관의 양허성 증가 효과 〉}

\begin{tabular}{|c|c|c|}
\hline 적용 할인율 & $10 \%$ & $7.04 \%$ \\
\hline 명목증여율1) & $70.1 \%$ & $56.3 \%$ \\
\hline 연평균 물가상승율 (1990-2005)2) & \multicolumn{2}{|l|}{$4.5 \%$} \\
\hline 실질증여율(p) & $82.2 \%$ & $75.7 \%$ \\
\hline 연평균 평가절하율 (1990-2005)2) & \multicolumn{2}{|l|}{$-2.3 \%$} \\
\hline 실질증여율(e) & $85.8 \%$ & $81.3 \%$ \\
\hline \multicolumn{3}{|c|}{ 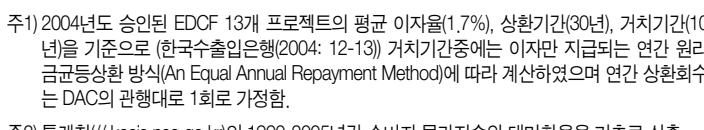 } \\
\hline \multicolumn{3}{|c|}{ 주2) 통계청 (/ kosis.nso.go.kr)의 1990-2005년간 소비자 물가지수와 대미환율을 기초로 산출 } \\
\hline
\end{tabular}

또한 〈그림1〉에서 보듯 일본과 함께 DAC회원국들 의 양자간 차관의 증여율이 상승하는 추세로 최근 에는 $70 \%$ 를 상회하고 있는바, $\mathrm{EDCF}$ 자체 명목 양허율도 $\mathrm{DAC}$ 의 양허성 제고권고에 따라 계속적 으로 상승 될것으로 기대되기 때문에 실질증여율 도 더욱 더 높아져 무상원조의 비용과 큰 차이가 발생되지 않는 재정부담을 가져다 줄 것으로 예상 된다.

4) 명목 상환액이 물가상승 지수(Inflation factor)에 의해 디플레이트되기 때문이다.

5) '04. 1.15 '05.1.14간 적용되는 CIRR은 5.79\%이며, 2004년도 EDCF 차관의 평균 상환기간은 30년으로서 마진은 $1.25 \%$ 가 추가 적용하게 되어 적용할 인율은 $7.04 \%$ 가 된다. 


\section{〈그림1〉. 양자간 원조차관의 증여율 추이 (승인기준)}

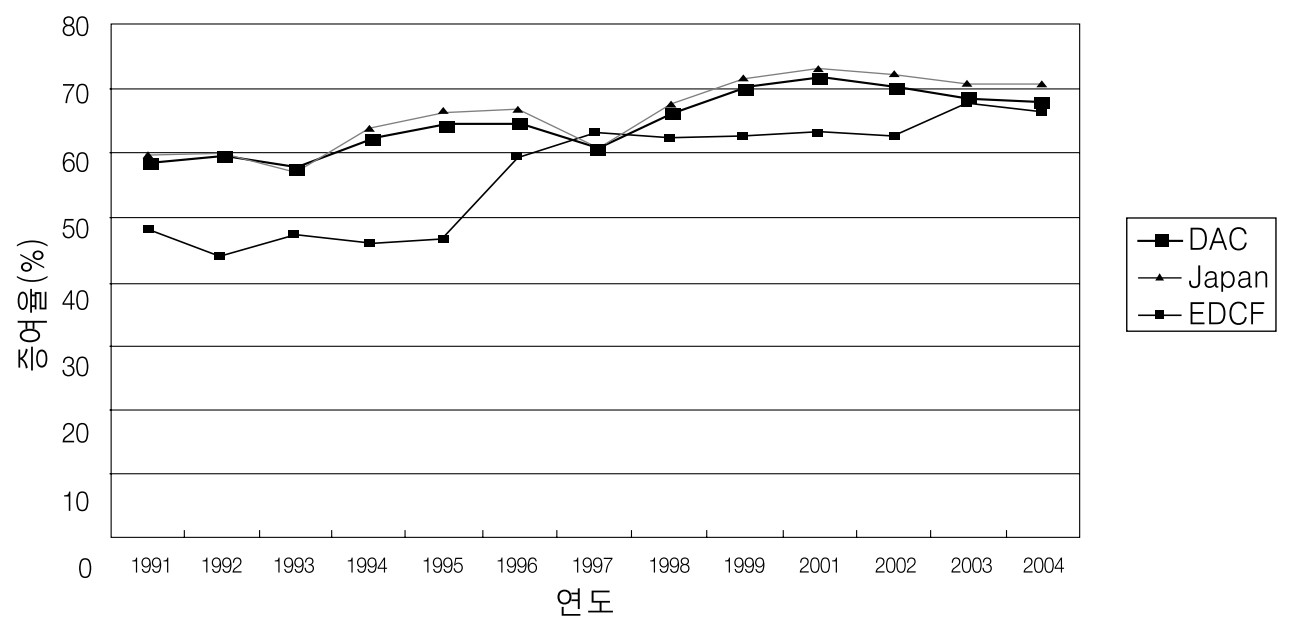

자료: 1. DAC보고서 (1992 2004)

2. 한국수출입은행(2004)

\section{3. 타이드론 활용의 제약}

원조차관-특히 타이드원조차관-은 $\mathrm{OECD}$ 의 규제 때문에 실질적으로 자금운용에 상당한 제약 을 가져오게 되었다. 그간 타이드 원조의 관행을 개선하려는 $\mathrm{DAC}$ 의 노력에도 불구하고 원조가 개 발목적에 적절히 사용되지 않고 무역 왜곡은 더욱 심화되었다. 개도국의 근본적인 빈곤퇴치를 위해 서는 대규모 인프라 구축도 필요하나 문제는 그 제 공 수단인 타이드 원조로 인한 공여국의 경제적 이 익의 경쟁적 도모에 있다. 1991 년의 $\mathrm{OECD}$ 각료회 의에서는 상업적 이익을 위해 사용되는 원조자금 을 제한하려는 목적이 달성되지 못하였음이 보고 되었다. 낮은 양허성 수준의 원조자금 사용이 증가 하였고 최빈국보다는 상대적으로 부유한 나라들에
원조자금이 집중되었다. 타이드원조는 사실상 공 여국 기업에 대한 수출 보조금인 성격 탓이다. 결 국 $\mathrm{OECD}$ 는 1992년 3월부터 일명 헬싱키패키지라 고 명명되는 공적수출신용협약(Arrangment on Officially Supported Export Credits)의 효력을 발효하여, 타이드된 양허성 신용으로 개도국이 재 정적(상업적)으로 실행가능한 (Financially/ Commercially viable) 프로젝트6)를 지원함으로써 나타나는 무역 왜곡을 방지하는 수단을 강구하게 되었다. 동 협약에 따라 중소득국과 저소득 최빈국 만이 양허성 차관을 지원받을 수있게 되었으며, 적 격국에 타이드 원조를 제공하려는 공여국은 사전 에 당해 프로젝트를 공지하여야 한다. 다만, 중저 소득국의 경우 양허성 수준(CL)이 $80 \%$ 이상이거

6) 정적(상업적)으로 실행가능하지 않는 프로젝트는 시장조건의 지원으로는 프로젝트 운영비와 차관상환에 충분한 자금흐름을 발생하기 어려운 프로젝트를 말한다. 
나 2 백만 $\mathrm{SDR}$ (약 2.8백만불)이하인 사업은 타이 드가 가능하게 되었다. 동 협약 시행후 에너지와 제조업 프로젝트는 특히 급격히 감소한 반면 사회 분야의 프로젝트가 주요 수혜자로 부상하게 되었 다 (Lammersen and Owen, 2001). 재정적으로 실행가능하지 않은 분야의 일반적 특성은 주된 산 출물이 공공재(예: 도로, 급수, 하수처리등), 단위 당 생산비가 높은 자본 집약적 프로젝트, 그리고 보통 가계의 소비자들인 수혜자 집단이 적정 시장 가격으로 산출물을 구입할 수 없는 분야 (예: 공공 교통시스템) 등이 해당되며 향후 동 협정의 기본정 신을 저해하는 근본적인 변화는 발생하지는 않을 전망이다.

\section{4. 원조의 질 저하}

이밖에 다른 요인으로 무상원조와 달리 차관 제 공은 공여국의 원조의 질에 영향을 미치게 되어 공 여국간 원조 부담에 관한 순위(Ranking)가 낮게 된다. 즉 차관의 비중이 높을수록 전체 양허성은 낮아지게 되어 원조의 질에 관한 한 $\mathrm{DAC}$ 의 권고 를 준수하지 않는 공여국으로서 이미지가 각인되 는 부담을 가지게 된다.

\section{IV. 우리나라 EDCF에의 영향}

양허성 차관 제공의 득실과 관련한 논란에도 불
구하고 적어도 우리나라의 수원 경험을 보면 앞서 지적한 바와 같이 개발차관이 우리나라의 경제 · 사회발전에 기여한 부분이 컸다는 평가를 받고 있 다. 따라서 이러한 우리나라의 수원경험을 기초로 공여국의 입장에서 양허성 개발차관의 유용성을 적극 활용할 필요가 있다. 그러나 우리나라의 성공 적인 개발경험은 매우 드문 사례에 속한다는 점과 $\mathrm{OECD}$ 의 타이드 론 규제는 실질적으로 차관 활용 을 어렵게 하고 있다. 특히, 우리나라가 1996년 $\mathrm{OECD}$ 에 가입함으로써 양허성 차관제공의 찬반에 대한 논거에 관계없이 전액 타이드론인 $\mathrm{EDCF}$ 운용 에 상당한 제약을 가져오게 되었다. 공적수출신용 협약에 적용을 받아 고중소득국 (UMIC) 이상의 고 소득국에 대한 타이드원조를 제공할 수 없으며 중 저소득국 (LMIC)과 기타 저소득국(LIC)에 대해서 는 상업성이 있는 프로젝트의 경우 타이드 론을 지 원할 수 없게 되었다. 따라서 차관상환능력이 있는 중저소득국 이상의 국가들에 대한 $\mathrm{EDCF}$ 지원은 사 실상 큰 차질을 빚게 되었다. 따라서 $\mathrm{LMIC}$ 및 $\mathrm{LIC}$ 국가군에 대해서는 상업성이 없는 사업을 발굴해 야만 하고 그렇지 않으면 타이드의 적용에서 제외 되는 최빈국을 대상으로한 사업을 발굴해야하는 어려움에 처하게 되었다. 양허성 수준 (CL)이 $80 \%$ 이상인 경우 타이드가 가능하지만 $\mathrm{EDCF}$ 의 $\mathrm{CIRR}$ 이 2002년 이후 계속적으로 $10 \%$ 이하로 하락하고 있어서 ${ }^{7)} \mathrm{CL}$ 을 $80 \%$ 이상으로 제고하기에는 실질적 으로 매우 어려운 상황이다. 그간 $\mathrm{EDCF}$ 는 중국,

7) 2005년 적용 CIRR 기준치는 $4.8 \%$ 에 불과하다. 
스리랑카, 인도네시아, 베트남등 중저소득국 이상 의 아시아지역을 중심으로 교통, 통신, 에너지등 산업인프라를 중심으로 지원하여 왔으나 $\mathrm{OECD}$ 가입 이후로는 타이드원조 제약으로 인해 규제대 상이 아닌 지역과 분야를 발굴하여 지원하게 되었 다. 그 결과 중저소득국중에서 상업성이 없는 사업 을 발굴하다보니 그간 전통적인 무상원조의 영역 으로 간주되던 의료 - 보건 및 교육부문에 대한 지 원이 ${ }^{8} 1996$ 년부터 증가하게 되어 유- 무상간 차별 성이 없는 국별 중복지원이라는 문제점도 나타나 게 되었다. 이러한 사회인프라에 대한 지원증가추 세는 당초 차관의 산업인프라건설 지원 이라는 가 장 기본적인 기능 수행이 불가불 제약을 받게됨에 따라 사회개발 목표 달성을 중점적으로 제시하고 있는 유엔의 천년개발목표(MDGs) 지원의 대외적 명분으로도 사용하고 있다. 또한 그동안 차관지원 결정에 가장 중요한 요인이었던 차관상환능력유무 가 가장 취약한 최빈국에도 1996년이후 지원이 점 차 증가하게 되었다. 1996년 이전에는 최빈국 지원 이 1 개국 정도에 불과하였으나 1996년에는 4 개국 지원으로 급증하였고 2000년 이후로는 매년 2 3 개국 수준의 지원을 유지하고 있다.

\section{$\mathrm{V}$. 결 론}

원조의 한 형태로서의 차관(Loans)제공에 대해
그동안 찬반의 논란이 있어 왔다. 개도국의 경제 사회발전에 필요한 장기저리의 투자자금을 공급하 여 왔다는 긍정적인 측면에도 불구하고 타이드 원 조차관은 개도국의 채무누적과 상환관리의 어려움 을 가중시켜왔다는 비판과 함께 빈곤한 개도국이 반드시 상환하여야 한다는 점에서 결국 개도국의 빈곤한 세금납세자들이 부유한 선진국의 기업들을 지원하게 된다는 모순도 제기되고 있어 타이드 원 조차관이 개발원조라는 명목하에 누가 혜택을 보 는가에 관한 의문을 일으킨다. 또한 차관 사용의 타당성은 예컨대 '차관' 이 대출비용을 초과하는 국민소득이나 외환을 추가로 증대시키거나 상환기 간 내 추가 소득을 발생시킨다던가 할 때이나 외채 를 효율적으로 잘 사용하여 경제성장에 기여를 한 사례는 우리나라의 경우를 제외하고는 극히 드물 다. 공여국의 입장에서도 인프레이션과 환율 변동 등의 요인을 반영한 실질비용을 감안하면 차관의 재정적 부담이 무상 못지않은 부담을 주게 된다. $\mathrm{DAC}$ 에서 가정하고 있는 고정할인율인 $10 \%$ 를 적 용하고 물가상승과 환율 하락율을 감안하면 실질 증여율은 $70.1 \%$ 에서 $85.5 \%$ 로 $15.4 \%$ 더 상승하게 된다. 양허성 수준 $(\mathrm{CL})$ 산출시 적용되는 할인율 $7.04 \%$ 를 기준으로 보면 실질 증여율은 $11.2 \%$ 더 증가된 $81.3 \%$ 에 달한다. 향후 $\mathrm{EDCF}$ 의 명목 증여 율은 차관지원 조건의 개선에 따라 더욱 증가가 예 상되고 설령 환율 변동분은 감안치 않더라도 최소 한 물가상승분 만큼은 추가로 상승하게 되어 무상

8) 1987년 2004년간 승인기준으로 EDCF 분야별 지원비중은 교통(26.4\%), 통신(19.35\%), 에너지(12.1\%), 보건(11.6\%), 교육(10.2\%), 상하수도 (8.0\%), 환 경(6.6\%), 농림수산(2.7\%), 제조업(1.2\%) 순이다. 특히 보건분야는 1996년부터는 2003년을 제외하고는 매년 지원결정이 내려지고 있다. 
원조의 부담수준과 큰 차이가 없는 수준에 이를 것 으로 예상된다. 수출보조금 성격의 타이드 원조가 공여국의 무역이익을 증진하는데 사용되었으나 국 제무역에서의 경쟁을 왜곡시키고 있음을 인지한 결과, $\mathrm{OECD}$ 는 헬싱키 패키지를 통해 기본적으로 상업적 재원을 조달할 수 없는 프로젝트에만 타이 드 원조를 사용토록 하고 있다. 따라서 타이드 론 에 대한 $\mathrm{OECD}$ 의 규제의 심화, 원조의 질 제고와 관련한 $\mathrm{DAC}$ 의 무상원조 중심의 추세 및 차관의 높은 양허율 추세등을 감안하면 개도국의 경제 사회개발 지원의 명분과 공여국에는 상환이라는 이점을 동시에 달성할 수 있었던 수단으로서의 차 관의 비중이 점차 하락할 수 밖에 없을 것으로 예
상된다. 우리의 원조차관인 $\mathrm{EDCF}$ 의 경우에도 타 이드 론 사용에 제약이 불가피하여 지원국 및 분야 선정 등 효율적인 지출 전략 마련이 더 긴요해 질 전망이다. 특히 적어도 중기적으로 기금출연이 감 축될 전망은 없어 보이므로 양허성 차관에 무상을 결합하는 혼합신용(Mixed Credit)등 다양한 형태 의 타이드 론 활용방안이 모색되리라고 본다. 아울 러 무상원조의 경우 타이드 규제가 $\mathrm{DAC}$ 가입전은 물론 가입 후에도 최빈국지원 부분만을 제외하면 현재로선 적용이 예외가 되므로 일반 기업들도 점 차 규모가 증대되고 있는 무상원조 프로젝트에 관 심을 가질 필요가 있다. 


\section{[ 참 고문 헌 ]}

- Harvey, C. (1983) Analysis of Project Finance in Developing Countries, Hampshire: Gower.

- Kambhampati, U. (2004) Development and the Developing World, Cambridge: Polity.

- Lammenersen, F. and A. Owen (2001) 'The Helsinki Arrangement: Its Impact on the Provision of Tied Aid', International Journal of Finance and Economics, 6: 69-70.

- Martens, J. (2001) 'Rethinking ODA: Toward a renewal of Official Development Assistance', A Discussion Paper for the United Nations Financing for Development Process, Global Policy Forum.

- Mikesell,R (1968) The Economics of Foreign Aid, London: Weidenfield and Nicolson.

- OECD (1985) Development Co-operation, Paris: OECD.

- Singer, H. (2001) International Development Co-operation, New York: Palgrave.

- Steinberg, D. (1985) Foreign Aid and the Development of the Republic of Korea: the Effectiveness of Concessional Assistance, Washington, D.C: AID.

- 한국국수출입은행(2004) 대외경제협력기금 업무통계, 서울: 한국수출입은행 